\title{
COMPLEXES OF HYDROGEN PEROXIDE AND DNA PHOSPHATE GROUP IN QUANTUM CHEMICAL CALCULATIONS
}

\section{D.V. Piatnytskyi, S.N. Volkov}

Bogolyubov Institute for Theoretical Physics, 14-b, Metrolohichna Str., Kyiv, 03143, Ukraine. e-mail:dvpyat@bitp.kiev.ua Submitted December 5, 2017

Accepted February 9, 2018

Background: Molecules of hydrogen peroxide $\left(\mathrm{H}_{2} \mathrm{O}_{2}\right)$ can be formed during radiolysis process in water medium after irradiation. A hypothesis about the possible role of hydrogen peroxide in blocking of processes of nonspecific DNA recognition by proteins is proposed in [1]. As one of the most long-living products, $\mathrm{H}_{2} \mathrm{O}_{2}$ molecules can diffuse considerable distances in the intracellular medium and reach DNA in the cell nucleus and form complexes with macromolecule phosphate groups. To confirm this hypothesis, the quantum chemical calculations of complexes structure of hydrogen peroxide molecule with atomic groups of the DNA backbone are performed.

Objectives: To determine the optimal geometries and formation energies of stable complexes of hydrogen peroxide with DNA phosphate group. To perform a comparative analysis of hydrogen peroxide and water molecules binding to phosphate group based on quantum chemical calculations.

Materials and Methods: The complexes which consist of phosphate group, hydrogen peroxide, water molecules, and sodium counterion are analyzed. The optimization of complex geometry and energy calculations is performed using the methods of quantum chemistry within Gaussian 03 software: HF/6$31+\mathrm{G}(\mathrm{d}, \mathrm{p}), \mathrm{MP} 2 / 6-31+\mathrm{G}(\mathrm{d}, \mathrm{p}), \mathrm{B} 3 \mathrm{LYP} / 6-31+\mathrm{G}(\mathrm{d}, \mathrm{p})$.

Results: This research shows that the hydrogen peroxide molecule as well as water molecule can form stable complexes with phosphate group, especially with the presence of sodium counterion $\mathrm{Na}^{+}$. The results of complex formation calculations with atom-atom potential functions method are confirmed. It is shown that the presence of sodium counterion significantly influences the geometry of the hydrogen peroxide complex with the phosphate group. The performed calculations indicate the possibility of hydrogen peroxide geometry change in the processes of complex formation.

Conclusions: The obtained results confirm the possibility of stable complexes forming for hydrogen peroxide and phosphate group. Prolonged situation of $\mathrm{H}_{2} \mathrm{O}_{2}$ molecule near the DNA backbone may block the nucleic-protein recognition processes as well as damage the macromolecule via decay into $\mathrm{OH}$ radicals in close proximity to double helix.

KEY WORDS: hydrogen peroxide; DNA phosphate group; stable complexes; quantum chemical calculations.

\section{КОМПЛЕКСИ ПЕРОКСИДУ ВОДНЮ І ФОСФАТНОЇ ГРУПИ ДНК В КВАНТОВО-ХІМІЧНИХ РОЗРАХУНКАХ} Д.В. П'ятницький, С.Н. Волков

Інститут теоретичної фізики ім. М.М. Боголюбова НАН України, вул. Метрологічна, 14 б, Київ, 03143, Україна

\begin{abstract}
Актуальність. Молекули пероксиду водню $\left(\mathrm{H}_{2} \mathrm{O}_{2}\right)$ можуть утворюватись в процесі радіолізу в водному середовищі після опромінення. Висунута гіпотеза [1] про можливу роль пероксиду водню в блокуванні процесів неспецифічного впізнавання ДНК білками. Як один 3 найбільш довго живучих продуктів, молекули $\mathrm{H}_{2} \mathrm{O}_{2}$ можуть дифундувати на значні відстані у внутрішньоклітинному середовищі, досягати ДНК в ядрі клітини і утворювати комплекси 3 фосфатними групами ДНК. Для підтвердження гіпотези в роботі виконано квантово-хімічні розрахунки структури комплексів молекули пероксиду водню з атомними групами остову ДНК.

Мета роботи. Визначення оптимальної геометрії та енергії утворення стабільних комплексів пероксиду водню з фосфатною групою ДНК. Провести порівняльний аналіз зв'язування пероксиду водню та молекули води з фосфатною групою на основі квантово-хімічних розрахунків.

Матеріали і методи. Розглядаються комплекси, що складаються 3 фосфатної групи, молекул пероксиду водню та води, протиіонів натрію. Виконано оптимізацію просторових геометрій комплексів та розрахунок енергій з використанням методів квантової хімії в рамках пакету Gaussian 03: HF/6-31+G(d,p), MP2/6-31+G(d,p), B3LYP/6-31+G(d,p).
\end{abstract}

(C) Piatnytskyi D.V., Volkov S.N., 2018 
Результати. Показано, що молекула пероксиду водню може утворювати комплекси з фосфатною групою не гірше за молекулу води, особливо в присутності протиіону натрію $\mathrm{Na}^{+}$. Підтверджені результати розрахунків комплексоутворення 3 використанням методу атом-атомних потенціальних функцій. Показано, що присутність протиіону натрію суттєво впливає на геометрію комплексу пероксиду водню з фосфатною групою. Проведені розрахунки вказують на можливість зміни геометрії молекули пероксиду водню у процесі комплексоутворення.

Висновки. Отримані результати підтверджують можливість утворення стабільних комплексів пероксиду водню 3 фосфатною групою ДНК. Тривале знаходження молекули $\mathrm{H}_{2} \mathrm{O}_{2}$ поряд 3 остовом ДНК може блокувати процеси нуклеїново-білкового впізнавання, а також призвести до пошкодження макромолекули внаслідок розпаду пероксиду на ОН-радикали безпосередньо біля подвійної спіралі.

КЛЮЧОВІ СЛОВА: пероксид водню; фосфатна група ДНК; стабільні комплекси; квантово-хімічні розрахунки.

\title{
КОМПЛЕКСЫ ПЕРОКСИДА ВОДОРОДА И ФОСФАТНОЙ ГРУППЫ ДНК В КВАНТОВО-ХИМИЧЕСКИХ РАСЧЕТАХ
}

Д.В. Пятницкий, С.Н. Волков

Институт теоретической физики им. Н.Н. Боголюбова НАН Украины, ул. Метрологическал, 14 б, Киев, 03143, Украина.

\begin{abstract}
Актуальность. Молекулы пероксида водорода $\left(\mathrm{H}_{2} \mathrm{O}_{2}\right)$ могут образовываться в процессе радиолиза в водной среде после облучения. Выдвинута гипотеза [1] о возможной роли пероксида водорода в блокировании процессов неспецифического узнавания ДНК белками. Как один из наиболее долгоживущих продуктов, молекулы $\mathrm{H}_{2} \mathrm{O}_{2}$ могут диффундировать на значительные расстояния во внутриклеточной среде, достигать ДНК в ядре клетки и образовывать комплексы с фосфатными группами ДНК. Для подтверждения гипотезы в работе выполнены квантово-химические расчеты структуры комплексов молекулы пероксида водорода с атомными группами остова ДНК.

Цель работы. Определение оптимальной геометрии и энергии образования стабильных комплексов пероксида водорода с фосфатной группой ДНК. Провести сравнительный анализ связывания пероксида водорода и молекулы воды с фосфатной группой на основе квантовохимических расчетов.
\end{abstract}

Материалы и методы. Рассматриваются комплексы, состоящие из фосфатной группы, молекул пероксида водорода и воды, противоионов натрия. Выполнена оптимизация пространственных геометрий комплексов и расчет энергий с использованием методов квантовой химии в рамках пакета Gaussian 03: HF/6-31+G(d,p), MP2/6-31+G(d,p), B3LYP/6-31+G(d,p).

Результаты. Показано, что молекула пероксида водорода может образовывать комплексы с фосфатной группой ДНК не хуже, чем молекула воды, особенно в присутствии противоиона натрия $\mathrm{Na}^{+}$. Подтверждены результаты расчетов комплексообразования с использованием метода атом-атомных потенциальных функций. Показано, что присутствие противоиона натрия существенно влияет на геометрию комплекса пероксида водорода с фосфатной группой. Проведенные расчеты указывают на возможность изменения геометрии молекулы пероксида водорода в процессе комплексообразования.

Выводы. Полученные результаты подтверждают возможность образования стабильных комплексов пероксида водорода с фосфатной группой. Длительное нахождение молекулы $\mathrm{H}_{2} \mathrm{O}_{2}$ рядом с остовом ДНК может блокировать процессы нуклеиново-белкового узнавания, а также привести к повреждению макромолекулы вследствие распада пероксида на ОН-радикалы в непосредственной близости возле двойной спирали.

КЛЮЧЕВЫЕ СЛОВА: пероксид водорода; фосфатная группа ДНК; стабильные комплексы; квантовохимические расчеты.

The interaction of small molecules with DNA double helix is the subject of special interest along last years. It is well known that some molecules can perform the important functions on regulation of the genetic activity of DNA in living cells. The understanding of mechanisms of these molecules action on DNA can be used for the development of new treatment methods and pharmacological drugs.

The interaction of hydrogen peroxide molecule with DNA has the significant interest. The peroxide molecules can be formed in water medium during the process of water radiolysis (see, for example, [2]) as a long-living product [3, 4]. Water radiolysis takes place when water volume is irradiated by different particles. The molecules of water medium decay 
Complexes of hydrogen peroxide and DNA phosphate group in quantum chemical...

into ions, radicals and molecular products (reactive oxygen species). In living cell radiolysis products interact with DNA macromolecule [5]. It is considered, that the most dangerous product is hydroxyl radical, because it induces double strand breaks which means complete destruction of DNA [6]. However, it is shown in Monte Carlo calculations [3, 4] that $\mathrm{OH}-$ radicals recombine quickly (during physico-chemical stage of radiolysis [2]) and so they interact with DNA macromolecule only if situated in close proximity. On the contrary, the hydrogen peroxide molecule can exist in intracellular medium for longer time and can diffuse on significant distances. So the $\mathrm{H}_{2} \mathrm{O}_{2}$ molecule has bigger probability to "find" DNA macromolecule in solution after irradiation. If peroxide is situated closely to DNA backbone it can decay into OH-radical via Fenton-type reaction [7] and thus damage it or it can somehow block DNA transcription. Such a mechanism of possible DNA damage in particle therapy was proposed in [1]. As considered, the DNA phosphate group can be the most probable site of interaction with molecules of medium, and particularly the $\mathrm{H}_{2} \mathrm{O}_{2}$ molecules.

It can be expected that study of interaction of hydrogen peroxide with DNA phosphate group can improve the methods of cancer treatment. Particle cancer therapy has especially good results when protons or heavy charged ions are used, because of well-known Bragg effect [8]. There are mechanisms of DNA damage in the processes of particle cancer therapy [9], among which are damage by secondary electrons and free radicals or the processes with shock waves [10]. But the question about physical mechanism which causes destruction of cancer cells remains yet opened [11]. It should be noted that in the works about alternative method of cancer therapy [12], the emphasis is made on hydrogen peroxide molecules forming in the cellular medium after injection of ascorbic acid. And also there are some experimental conclusions about selective damaging of cancer cells by hydrogen peroxide apart from healthy [13].

In the present work the quantum-chemical calculations are carried out for complexes which consist of hydrogen peroxide and water molecules, phosphate group and sodium counterion. We consider isolated phosphate group, but charges on its atoms are taken to correspond to the distribution of charges on the atoms of the sugar-phosphate DNA backbone. We take into account sodium counterion, because under physiological conditions DNA phosphate groups are usually neutralized by counterions of the solution. The optimized geometries of single molecules, double and triple complexes are obtained, energies are calculated. The Hartree-Fock, density functional theory and MP2 methods are used. Results presented in this work continue our earlier calculations from [1], where atom-atom potential functions method was used.

The calculations made in the present work are more accurate than calculations from [1]. The geometry optimizations in complexes provided with much better quality, the flexibility of molecules is taken into account (molecules can slightly change their structure in different complexes), all atoms in phosphate group are considered.

\section{METHOD OF CALCULATION}

Quantum-chemical calculations of single molecules and complexes are performed with Hartree-Fock theory $(\mathrm{HF} / 6-31+\mathrm{G}(\mathrm{d}, \mathrm{p}))$, Møller-Plesset perturbation theory (MP2/6$31+\mathrm{G}(\mathrm{d}, \mathrm{p}))$ and density functional theory $(\mathrm{B} 3 \mathrm{LYP} / 6-31+\mathrm{G}(\mathrm{d}, \mathrm{p}))$ together with geometry optimizations. The Gaussian 03 software is used in calculations [14], Facio software is used for visualization [15].

Thus, as a first step, the geometry optimizations for single objects (molecules $\mathrm{H}_{2} \mathrm{O}_{2}$ and $\mathrm{H}_{2} \mathrm{O}$, phosphate group) are made. Then the calculations are made for double complexes $\mathrm{H}_{2} \mathrm{O}_{2}-\mathrm{PO}_{4}^{-}, \mathrm{H}_{2} \mathrm{O}-\mathrm{PO}_{4}^{-}, \mathrm{Na}^{+}-\mathrm{H}_{2} \mathrm{O}_{2}, \mathrm{Na}^{+}-\mathrm{H}_{2} \mathrm{O}$ and $\mathrm{Na}^{+}-\mathrm{PO}_{4}^{-}$. Geometry optimizations are performed, interaction energies are calculated. And, at last, there are calculations of energies and geometries for triple complexes $\mathrm{Na}^{+}-\mathrm{H}_{2} \mathrm{O}_{2}-\mathrm{PO}_{4}^{-}, \mathrm{Na}^{+}-\mathrm{H}_{2} \mathrm{O}-\mathrm{PO}_{4}{ }^{-}$. The main purpose of 
this work is comparison of peroxide-phosphate interaction with water-phosphate interaction with and without sodium counterion.

In the present work we consider the interaction energy of double complex $\mathrm{AB}$ as a difference between electronic energy of $\mathrm{AB}$ and its components $\mathrm{A}$ and $\mathrm{B}$

$$
\Delta E_{A B}=E_{A B}(A B)-E_{A}(A)-E_{B}(B) .
$$

For triple complex $\mathrm{ABC}$ we have

$$
\Delta E_{A B C}=E_{A B C}(A B C)-E_{A}(A)-E_{B}(B)-E_{C}(C) .
$$

The basis set is presented in brackets. To avoid the basis set superposition error the counterpoise correction is made [16]

$$
\begin{gathered}
\Delta E_{A B}^{C P}=E_{A B}(A B)-E_{A}(A B)-E_{B}(A B) \\
\Delta E_{A B C}^{C P}=E_{A B C}(A B C)-E_{A}(A B C)-E_{B}(A B C)-E_{C}(A B C) .
\end{gathered}
$$

Also deformation energy should be introduced because of difference between the geometries of isolated molecules and of those within complexes

$$
E_{\text {def }}=\sum_{i}\left(E_{i}^{\text {complex }}-E_{i}^{\text {isolated }}\right),
$$

which is a difference between electronic energies of molecule in complex and isolated molecule. Then interaction energy in complex can be calculated by formula

$$
\Delta E=\Delta E^{C P}+E_{\text {def }} .
$$

In the present work we used formula (6) to calculate interaction energies in double complexes $\left(\mathrm{H}_{2} \mathrm{O}_{2}-\mathrm{PO}_{4}^{-}, \mathrm{H}_{2} \mathrm{O}-\mathrm{PO}_{4}^{-}, \mathrm{Na}^{+}-\mathrm{PO}_{4}^{-}, \mathrm{Na}^{+}-\mathrm{H}_{2} \mathrm{O}_{2}, \mathrm{Na}^{+}-\mathrm{H}_{2} \mathrm{O}\right)$ and triple complexes $\left(\mathrm{Na}^{+}-\mathrm{H}_{2} \mathrm{O}_{2}-\right.$ $\mathrm{PO}_{4}^{-}, \mathrm{Na}^{+}-\mathrm{H}_{2} \mathrm{O}-\mathrm{PO}_{4}^{-}$).

\section{RESULTS AND DISCUSSION}

Geometry optimizations of hydrogen peroxide and water molecules, and phosphate group $\mathrm{PO}_{4}{ }^{-}$are performed in methods $\mathrm{HF} / 6-31+\mathrm{G}(\mathrm{d}, \mathrm{p}), \mathrm{MP} 2 / 6-31+\mathrm{G}(\mathrm{d}, \mathrm{p}), \mathrm{B} 3 \mathrm{LYP} / 6-31+\mathrm{G}(\mathrm{d}, \mathrm{p})$.

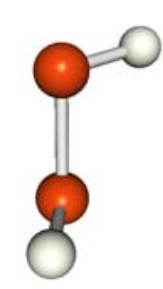

(a)

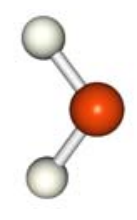

(b)

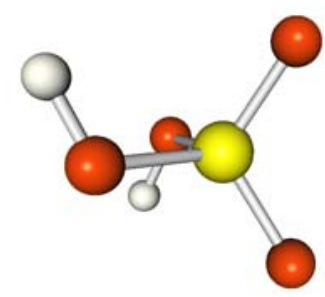

(c)

Fig. 1. Hydrogen peroxide (a), water (b) molecules, phosphate group (c). Oxygen atoms are shown in red, hydrogen - white, phosphor - yellow.

The hydrogen peroxide molecule (Fig. 1(a)) is symmetric and characterized by distances between two oxygen atoms and between oxygen and hydrogen atoms, by two equal angles $\mathrm{O}$ - 
Complexes of hydrogen peroxide and DNA phosphate group in quantum chemical...

$\mathrm{O}-\mathrm{H}$ and by dihedral angle $\mathrm{H}-\mathrm{O}-\mathrm{O}-\mathrm{H}$. The values of these distances and angles obtained from geometry optimizations are presented in Table 1.

Table 1. Geometry of hydrogen peroxide molecule $\mathrm{H}_{2} \mathrm{O}_{2}$

\begin{tabular}{|c|c|c|c|c|}
\hline & O-O $(\AA)$ & H-O $(\AA)$ & LO-O-H $\left(^{\circ}\right)$ & Dihedral angle $\left(^{\circ}\right)$ \\
\hline $\begin{array}{c}\mathrm{HF} / \\
6-31+\mathrm{G}(\mathrm{d}, \mathrm{p})\end{array}$ & 1.39 & 0.95 & 102.7 & 116.8 \\
\hline $\begin{array}{c}\mathrm{B} 3 \mathrm{LYP} / \\
6-31+\mathrm{G}(\mathrm{d}, \mathrm{p})\end{array}$ & 1.46 & 0.97 & 100.3 & 119.4 \\
\hline $\begin{array}{c}\mathrm{MP} 2 / \\
6-31+\mathrm{G}(\mathrm{d}, \mathrm{p})\end{array}$ & 1.47 & 0.97 & 99 & 121.4 \\
\hline
\end{tabular}

The distances and angles shown in Table 1 are close to each other for different methods of optimizations, and also they are comparable with values obtained in [17] by similar calculations. It should be mentioned that the dihedral angle $\mathrm{H}-\mathrm{O}-\mathrm{O}-\mathrm{H}$ can be very sensitive to environment. Thus it can be considerably different for isolated molecule and molecule in complex.

The calculations for water molecule are analogous, results are presented in Table 2. These results are also close to each other for different types of calculations.

The geometry of phosphate group is more complicated (Fig. 1(c)). So we do not present all distances and angles, just the distance between two oxygen atoms, which contain negative charge. Group $\mathrm{PO}_{4}{ }^{-}$considered as a part of DNA backbone, but two hydrogen atoms are placed instead of bounds to backbone (towards atoms C3' and $\mathrm{C}^{\prime}$ '). The charge of $\mathrm{PO}_{4}{ }^{-}$is -1 of elementary electronic charge. It is interesting to study the interaction of hydrogen peroxide and water molecules, sodium counterion relatively to two negatively charged oxygen atoms. The distances between these oxygen atoms are shown in Table 2 for different methods of calculations, though they are nearly equal.

Table 2. Geometry of water molecule and distance between two oxygen atoms in $\mathrm{PO}_{4}{ }^{-}$

\begin{tabular}{|c|c|c|c|}
\hline & H-O $(\AA)$ & LO-O-H $\left(^{\circ}\right)$ & O-O in PO $_{4}^{-}(\AA)$ \\
\hline HF/6-31+G(d,p) & 0.94 & 107.2 & 2.62 \\
\hline $\begin{array}{c}\text { B3LYP/6- } \\
\text { 31+G(d,p) }\end{array}$ & 0.97 & 105.7 & 2.69 \\
\hline MP2/6-31+G(d,p) & 0.96 & 105.4 & 2.70 \\
\hline
\end{tabular}

\section{Double complexes}

Complexes $\mathrm{H}_{2} \mathrm{O}_{2}-\mathrm{PO}_{4}^{-}, \mathrm{H}_{2} \mathrm{O}-\mathrm{PO}_{4}^{-}, \mathrm{Na}^{+}-\mathrm{PO}_{4}^{-}, \mathrm{Na}^{+}-\mathrm{H}_{2} \mathrm{O}_{2}$ and $\mathrm{Na}^{+}-\mathrm{H}_{2} \mathrm{O}$ are considered. The geometry optimizations are carried out for these complexes, energies of interaction are calculated.

Let us consider the double complexes $\mathrm{H}_{2} \mathrm{O}_{2}-\mathrm{PO}_{4}{ }^{-}$and $\mathrm{H}_{2} \mathrm{O}-\mathrm{PO}_{4}{ }^{-}$. Their optimized geometries are shown on Fig. 2. It should be mentioned, that we take into account only complexes, where peroxide or water molecules are situated near two "opened" oxygen atoms (on the right side of $\mathrm{PO}_{4}^{-}$on Fig. 2), because group $\mathrm{PO}_{4}^{-}$is considered as a part of DNA backbone.

Double complexes have the geometries (Fig. 2) where hydrogen peroxide or water molecule is situated almost symmetrically near oxygen atoms of $\mathrm{PO}_{4}^{-}$. In the case of hydrogen peroxide there are two hydrogen bonds (upper and lower symmetrically), because average distance between neighbor oxygen atom (from $\mathrm{PO}_{4}^{-}$) and hydrogen (from $\mathrm{H}_{2} \mathrm{O}_{2}$ ) is 
$1.85 \AA$, angle $\mathrm{O}-\mathrm{H}-\mathrm{O} 163^{\circ}$. The hydrogen peroxide molecule is compressed - its dihedral angle smaller than in Table 1 and is close to $55^{\circ}$. Such a change in dihedral angle makes a contribution into deformation energy (about 3-4 kcal/mol for different methods). On the contrary, the water molecule does not form hydrogen bonds with oxygen atoms of $\mathrm{PO}_{4}{ }^{-}$ because of its smaller size, but it is also situated symmetrically to them. For water molecule the symmetrical distances $\mathrm{O}\left(\mathrm{PO}_{4}{ }^{-}\right)-\mathrm{H}\left(\mathrm{H}_{2} \mathrm{O}\right)$ are more than $2.1 \AA$ and angles $\mathrm{O}-\mathrm{H}-\mathrm{O}$ are near $145^{\circ}$ and these geometries are insufficient for forming of hydrogen bonds.

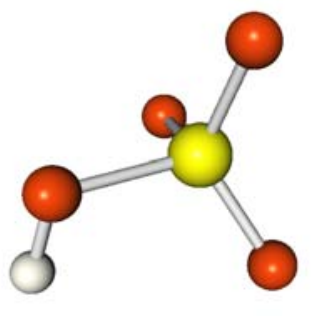

(a)

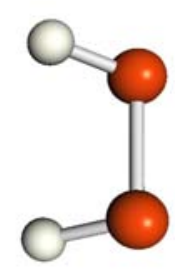

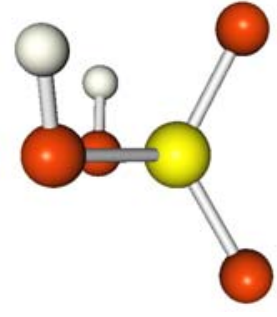

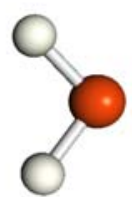

(b)

Fig. 2. Complexes $\mathrm{H}_{2} \mathrm{O}_{2}-\mathrm{PO}_{4}^{-}$(a) and $\mathrm{H}_{2} \mathrm{O}-\mathrm{PO}_{4}^{-}$(b).

Interaction energies of complexes $\mathrm{H}_{2} \mathrm{O}_{2}-\mathrm{PO}_{4}{ }^{-}$and $\mathrm{H}_{2} \mathrm{O}-\mathrm{PO}_{4}{ }^{-}$are shown in Table 3. From Table 4 one can see that the energies of complex with hydrogen peroxide molecule and phosphate group are larger for every method of calculation. Complexes of water molecule and $\mathrm{PO}_{4}^{-}$have smaller energy. The hydrogen peroxide molecule is larger than water molecule and it is more convenient for hydrogen peroxide to form two symmetric hydrogen bonds with phosphate group.

Table 3. Energies of $\mathrm{H}_{2} \mathrm{O}_{2}-\mathrm{PO}_{4}^{-}$and $\mathrm{H}_{2} \mathrm{O}-\mathrm{PO}_{4}{ }^{-}$double complexes (energies $-\mathrm{kcal} / \mathrm{mol}$ )

\begin{tabular}{|c|c|c|}
\hline & $\mathrm{H}_{2} \mathrm{O}_{2}-\mathrm{PO}_{4}^{-}$ & $\mathrm{H}_{2} \mathrm{O}_{-}^{-} \mathrm{PO}_{4}^{-}$ \\
\hline $\mathrm{HF} / 6-31+\mathrm{G}(\mathrm{d}, \mathrm{p})$ & -20.8 & -14.8 \\
\hline $\mathrm{B} 3 \mathrm{LYP} / 6-31+\mathrm{G}(\mathrm{d}, \mathrm{p})$ & -21.3 & -14.4 \\
\hline $\mathrm{MP} 2 / 6-31+\mathrm{G}(\mathrm{d}, \mathrm{p})$ & -21.4 & -15.0 \\
\hline
\end{tabular}

The double complexes with sodium counterion are also considered in the present work. These are complexes $\mathrm{Na}^{+}-\mathrm{PO}_{4}{ }^{-}, \mathrm{Na}^{+}-\mathrm{H}_{2} \mathrm{O}_{2}$ and $\mathrm{Na}^{+}-\mathrm{H}_{2} \mathrm{O}$. Optimized geometries of complexes are shown on Fig. 3. In the complex of sodium counterion and phosphate group the distance $\mathrm{Na}^{+}-\mathrm{P}$ is $2.68 \AA$ (mean for three methods). Distances $\mathrm{Na}^{+}-\mathrm{O}$ for complexes $\mathrm{Na}^{+}-\mathrm{H}_{2} \mathrm{O}_{2}$ and $\mathrm{Na}^{+}-\mathrm{H}_{2} \mathrm{O}$ are $2.38 \AA$ and $2.24 \AA$ correspondingly. For comparison, the distances calculated by atom-atom potential function method [1] were $2.8 \AA\left(\mathrm{Na}^{+}-\mathrm{H}_{2} \mathrm{O}_{2}\right.$ complex) and $2.7 \AA\left(\mathrm{Na}^{+}-\right.$ $\mathrm{H}_{2} \mathrm{O}$ complex).

The energies of $\mathrm{Na}^{+}-\mathrm{PO}_{4}{ }^{-}, \mathrm{Na}^{+}-\mathrm{H}_{2} \mathrm{O}_{2}$ and $\mathrm{Na}^{+}-\mathrm{H}_{2} \mathrm{O}$ complexes are shown in Table 4. It should be mentioned that the complex of sodium and phosphate group is the most strongly bounded, whereas molecules of peroxide and water interact with sodium counterion almost equally. The results of previous calculations [1] gave the energies $-122 \mathrm{kcal} / \mathrm{mol}\left(\mathrm{Na}^{+}-\mathrm{PO}_{4}{ }^{-}\right)$, $14 \mathrm{kcal} / \mathrm{mol}\left(\mathrm{Na}^{+}-\mathrm{H}_{2} \mathrm{O}_{2}\right)$ and $-12 \mathrm{kcal} / \mathrm{mol}\left(\mathrm{Na}^{+}-\mathrm{H}_{2} \mathrm{O}\right)$. 
Complexes of hydrogen peroxide and DNA phosphate group in quantum chemical...

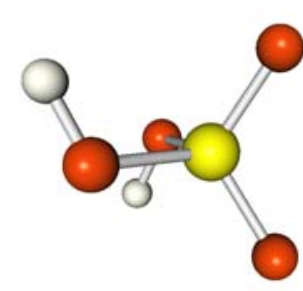

(a)

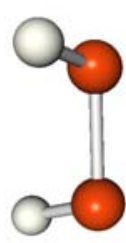

(b)

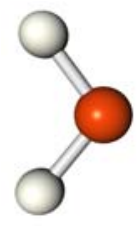

(c)

Fig. 3. Complexes $\mathrm{Na}^{+}-\mathrm{PO}_{4}^{-}$(a), $\mathrm{Na}^{+}-\mathrm{H}_{2} \mathrm{O}_{2}$ (b), and $\mathrm{Na}^{+}-\mathrm{H}_{2} \mathrm{O}$ (c). Sodium counterion is shown in blue.

Table 4. Energies of complexes $\mathrm{Na}^{+}-\mathrm{PO}_{4}^{-}, \mathrm{Na}^{+}-\mathrm{H}_{2} \mathrm{O}_{2}$ and $\mathrm{Na}^{+}-\mathrm{H}_{2} \mathrm{O}(\mathrm{kcal} / \mathrm{mol})$

\begin{tabular}{|c|c|c|c|}
\hline & $\mathrm{Na}^{+}-\mathrm{PO}_{4}^{-}$ & $\mathrm{Na}^{+}-\mathrm{H}_{2} \mathrm{O}_{2}$ & $\mathrm{Na}^{+}-\mathrm{H}_{2} \mathrm{O}$ \\
\hline $\mathrm{HF} / 6-31+\mathrm{G}(\mathrm{d}, \mathrm{p})$ & -135.9 & -24.1 & -24.9 \\
\hline $\mathrm{B} 3 \mathrm{LYP} / 6-31+\mathrm{G}(\mathrm{d}, \mathrm{p})$ & -134.8 & -24.4 & -25.0 \\
\hline $\mathrm{MP} 2 / 6-31+\mathrm{G}(\mathrm{d}, \mathrm{p})$ & -130.7 & -22.6 & -23.6 \\
\hline
\end{tabular}

The energies of $\mathrm{Na}^{+}-\mathrm{H}_{2} \mathrm{O}_{2}$ complex obtained from quantum-chemical calculations are slightly smaller than energies of $\mathrm{Na}^{+}-\mathrm{H}_{2} \mathrm{O}$ complex, whereas for calculation with atom-atom potential functions method these values are vise versa. This difference can be explained by flexibility of hydrogen peroxide molecule. In quantum-chemical calculation $\mathrm{H}_{2} \mathrm{O}_{2}$ can change its geometry (especially, dihedral angle) near the counterion, while the geometry change in water molecule is less significant. In method used in [1] the molecules $\mathrm{H}_{2} \mathrm{O}_{2}$ and $\mathrm{H}_{2} \mathrm{O}$ were rigid and did not change their geometries.

\section{Triple complexes}

Triple complexes $\mathrm{Na}^{+}-\mathrm{H}_{2} \mathrm{O}_{2}-\mathrm{PO}_{4}{ }^{-}$and $\mathrm{Na}^{+}-\mathrm{H}_{2} \mathrm{O}-\mathrm{PO}_{4}{ }^{-}$is studied. It is interesting to add sodium counterion to double complexes $\mathrm{H}_{2} \mathrm{O}_{2}-\mathrm{PO}_{4}^{-}$and $\mathrm{H}_{2} \mathrm{O}-\mathrm{PO}_{4}^{-}$, because sodium interacts with phosphate stronger than molecules $\mathrm{H}_{2} \mathrm{O}_{2}$ and $\mathrm{H}_{2} \mathrm{O}$, and sodium counterions are always present in the solution in natural conditions. Optimized structures of such complexes are shown on Fig. 4. We consider sodium counterion and hydrogen peroxide or water molecules to be placed near two "opened" oxygen atoms of $\mathrm{PO}_{4}^{-}$(to the right of phosphate group on Fig. 4).

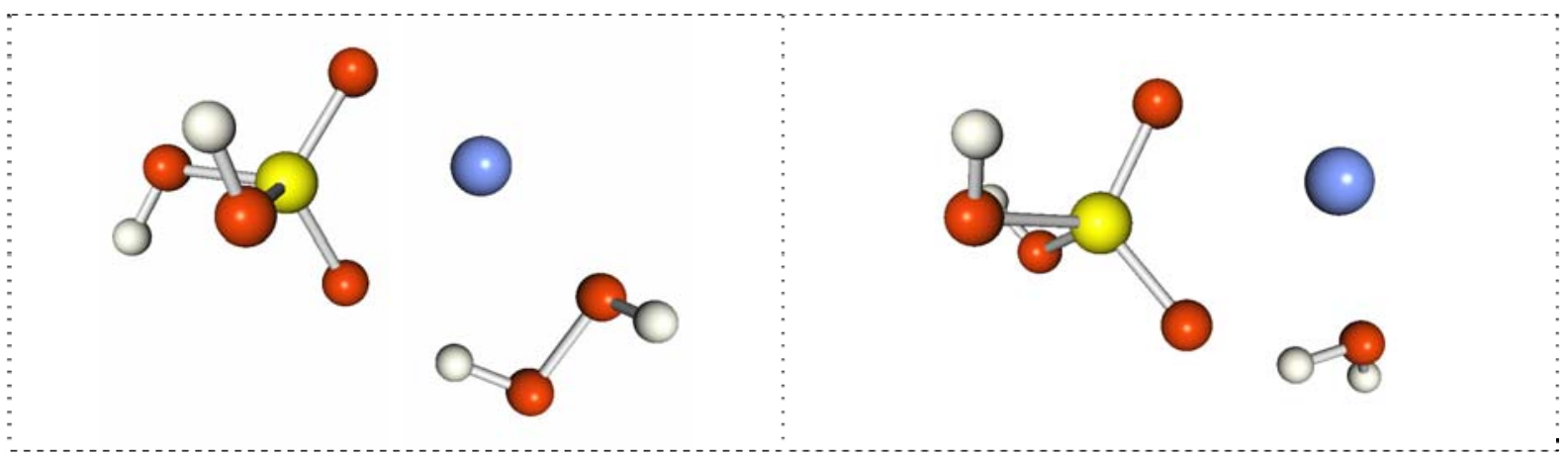

(a)

(b)

Fig. 4. Complexes $\mathrm{Na}^{+}-\mathrm{H}_{2} \mathrm{O}_{2}-\mathrm{PO}_{4}^{-}$(a) and $\mathrm{Na}^{+}-\mathrm{H}_{2} \mathrm{O}-\mathrm{PO}_{4}^{-}$(b).

These geometries are almost similar for different type of calculation. Geometry optimization shows that adding of sodium counterion into double complexes $\mathrm{H}_{2} \mathrm{O}_{2}-\mathrm{PO}_{4}{ }^{-}$and $\mathrm{H}_{2} \mathrm{O}-\mathrm{PO}_{4}{ }^{-}$leads to displacement of peroxide or water molecule while sodium is situated 
closer to $\mathrm{PO}_{4}{ }^{-}$. Molecule $\mathrm{H}_{2} \mathrm{O}_{2}\left(\mathrm{H}_{2} \mathrm{O}\right)$ forms one hydrogen bond with phosphate group. It is natural that sodium counterion is situated close to $\mathrm{PO}_{4}^{-}$, because it has positive charge and oxygen atoms of $\mathrm{PO}_{4}^{-}$have negative and also sodium repulses positively charged hydrogen atoms of peroxide or water molecules which form hydrogen bonds with $\mathrm{PO}_{4}^{-}$. It should be noted that in previous work [1] optimal geometries were different, but optimization with efficient quantum-chemical methods shows that such a geometries are not minima of potential surface and geometries (Fig. 4) are more energetically convenient. Interaction energies of complexes $\mathrm{Na}^{+}-\mathrm{H}_{2} \mathrm{O}_{2}-\mathrm{PO}_{4}^{-}$and $\mathrm{Na}^{+}-\mathrm{H}_{2} \mathrm{O}-\mathrm{PO}_{4}^{-}$are shown in Table 5. One can see that both complexes are bound. Complex with hydrogen peroxide is bound slightly stronger than complex with water molecule.

Table 5. Energies of complexes $\mathrm{Na}^{+}-\mathrm{H}_{2} \mathrm{O}_{2}-\mathrm{PO}_{4}{ }^{-}$and $\mathrm{Na}^{+}-\mathrm{H}_{2} \mathrm{O}-\mathrm{PO}_{4}{ }^{-}$(energies $-\mathrm{kcal} / \mathrm{mol}$ )

\begin{tabular}{|c|c|c|}
\hline & $\mathrm{Na}^{+}-\mathrm{H}_{2} \mathrm{O}_{2}-\mathrm{PO}_{4}^{-}$ & $\mathrm{Na}^{+}-\mathrm{H}_{2} \mathrm{O}-\mathrm{PO}_{4}^{-}$ \\
\hline $\mathrm{HF} / 6-31+\mathrm{G}(\mathrm{d}, \mathrm{p})$ & -154.0 & -151.4 \\
\hline $\mathrm{B} 3 \mathrm{LYP} / 6-31+\mathrm{G}(\mathrm{d}, \mathrm{p})$ & -154.0 & -152.1 \\
\hline $\mathrm{MP} 2 / 6-31+\mathrm{G}(\mathrm{d}, \mathrm{p})$ & -148.2 & -148.0 \\
\hline
\end{tabular}

These results are qualitatively similar to results from [1], obtained in atom-atom potential functions method, where energies of complexes $\mathrm{Na}^{+}-\mathrm{H}_{2} \mathrm{O}_{2}-\mathrm{PO}_{4}{ }^{-}$and $\mathrm{Na}^{+}-\mathrm{H}_{2} \mathrm{O}-\mathrm{PO}_{4}{ }^{-}$were $130.3 \mathrm{kcal} / \mathrm{mol}$ and $-129.2 \mathrm{kcal} / \mathrm{mol}$ correspondingly. But there are different geometries of complexes [1]. The triple complex $\mathrm{Na}^{+}-\mathrm{H}_{2} \mathrm{O}_{2}-\mathrm{PO}_{4}^{-}$with geometry similar to [1] is not optimal and has energy near $-147 \mathrm{kcal} / \mathrm{mol}$, whereas its energy in geometry Fig. 4(a) is $-154 \mathrm{kcal} / \mathrm{mol}$ for $\mathrm{HF} / 6-31+\mathrm{G}(\mathrm{d}, \mathrm{p})$ calculation.

\section{CONCLUSIONS}

The main result of the present work is showing that hydrogen peroxide molecule can form stable complexes with phosphate group of DNA with or without sodium counterion. Energetically it is similar to water molecule. But since the $\mathrm{H}_{2} \mathrm{O}_{2}$ molecule has bigger mass it can stay near DNA backbone for longer time. Thus, there are two possible ways for peroxide to interact with DNA backbone near phosphate groups - decay via Fenton reaction or direct transcription blocking.

As a future prospect we plan to investigate such complexes with water solution model to obtain results more close to natural conditions. It is also interesting to analyze the behavior of hydrogen peroxide molecules near DNA within molecular dynamics calculation.

\section{ACKNOWLEDGMENTS}

The present work is partially supported by the program "Grid infrastructure and Grid technologies for scientific and applied applications" (project number 0117U003429).

\section{CONFLICT OF INTEREST}

The authors declare that there is no conflict of interest.

D.V. Piatnytskyi (iD) 0000-0002-8809-005X

\section{Author's ORCID ID}

\section{REFERENCES}

1. Piatnytskyi D. V., Zdorevskyi O. O., Perepelytsya S. M., Volkov S. N. Understanding the mechanism of DNA deactivation in ion therapy of cancer cells: hydrogen peroxide action // Eur. Phys. J. D. 2015. Vol. 69, P. 255.

2. Le Caer S. Water Radiolysis: Influence of oxide surfaces on $\mathrm{H}_{2}$ production under ionizing radiation // Water. 2011. Vol. 3, P. 235-253. 
Complexes of hydrogen peroxide and DNA phosphate group in quantum chemical...

3. Kreipl M. S., Friedland W., Paretzke H. G. Time- and space-resolved Monte Carlo study of water radiolysis for photon, electron and ion irradiation // Radiat. Environ. Biophys. 2009. Vol. 48, P. 11-20.

4. Uehara S., Nikjoo H. Monte Carlo simulation of water radiolysis for low-energy charged particles // J. Radiat. Res. 2006. Vol. 47, P. 69-81.

5. Manda G., Nechifor M. T., Neagu T.-M. Reactive oxygen species, cancer and anti-cancer therapies // Current Chemical Biology. 2009. Vol. 3, P. 342-366.

6. Timofeev-Ressovsky N. W., Savich A. V., Shal'nov M. I. Introduction to Molecular Radiobiology: PhysicoChemical Foundations. Moscow: Medicina, 1981. 320 p. (in Russian)

7. Fenton H. J. H. Oxidation of tartaric acid in presence of iron // J. Chem. Soc., Trans. 1894. Vol. 65, P. 899911.

8. Kraft G. Tumor therapy with heavy charged particles // Progress in Particle and Nuclear Physics. 2000. Vol. 45, P. S473-S544.

9. Solov'yov A. V., Surdutovich E., Scifoni E., Mishustin I., Greiner W. Physics of ion beam cancer therapy: A multiscale approach / Phys. Rev. E. 2009. Vol. 79, P. 011909.

10. Surdutovich E., Yakubovich A. V., Solov'yov A. V. Biodamage via shock waves initiated by irradiation with ions // Sci. Rep. 2013. Vol. 3, P. 1289.

11. Krämer M., Durante M. Ion beam transport calculations and treatment plans in particle therapy // Eur. Phys. J. D. 2010. Vol. 60, P. 195-202.

12. Parrow N. L., Leshin J. A., Levine M. Parenteral ascorbate as a cancer therapeutic: a reassessment based on pharmacokinetics // Antioxidants \& Redox Signaling. 2013. Vol. 19, N 17, P. 2141-2156.

13. Chen Q., Espey M. G., Krishna M. C., Mitchell J. B., Corpe C. P., Buettner G. R., Shacter E., Levine M. Pharmacologic ascorbic acid concentrations selectively kill cancer cells: action as a pro-drug to deliver hydrogen peroxide to tissues / PNAS. 2005. Vol. 102, N 38, P. 13604-13609.

14. Gaussian 03, Revision C.02. Frisch M. J., Trucks G. W., Schlegel H. B., Scuseria G. E., Robb M. A., Cheeseman J. R., Montgomery Jr. J. A., Vreven T., Kudin K. N., Burant J. C., Millam J. M., Iyengar S. S., Tomasi J., Barone V., Mennucci B., Cossi M., Scalmani G., Rega N., Petersson G. A., Nakatsuji H., Hada M., Ehara M., Toyota K., Fukuda R., Hasegawa J., Ishida M., Nakajima T., Honda Y., Kitao O., Nakai H., Klene M., Li X., Knox J. E., Hratchian H. P., Cross J. B., Bakken V., Adamo C., Jaramillo J., Gomperts R., Stratmann R. E., Yazyev O., Austin A. J., Cammi R., Pomelli C., Ochterski J. W., Ayala P. Y., Morokuma K., Voth G. A., Salvador P., Dannenberg J. J., Zakrzewski V. G., Dapprich S., Daniels A. D., Strain M. C., Farkas O., Malick D. K., Rabuck A. D., Raghavachari K., Foresman J. B., Ortiz J. V., Cui Q., Baboul A. G., Clifford S., Cioslowski J., Stefanov B. B., Liu G., Liashenko A., Piskorz P., Komaromi I., Martin R. L., Fox D. J., Keith T., Al-Laham M. A., Peng C. Y., Nanayakkara A., Challacombe M., Gill P. M. W., Johnson B., Chen W., Wong M. W., Gonzalez C., and Pople J. A., Gaussian Inc., Wallingford CT, 2004.

15. Suenaga M. Facio: new computational chemistry environment for PC GAMESS // Journal of Computer Chemistry, Japan. 2005. Vol. 4 (1), P. 25-32.

16. Boys S. F., Bernardi F. The calculation of small molecular interactions by the differences of separate total energies. Some procedures with reduced errors // Mol. Phys. 1970. Vol. 19 (4), P. 553-566.

17. Gonzalez L., Mo O., Yanez M. High-level ab initio versus DFT calculations on $\left(\mathrm{H}_{2} \mathrm{O}_{2}\right)_{2}$ and $\mathrm{H}_{2} \mathrm{O}_{2}-\mathrm{H}_{2} \mathrm{O}$ complexes as prototypes of multiple hydrogen bond systems // J. Comput. Chem. 1997. Vol. 18, P. 11241135 .

\section{REFERENCES}

1. Piatnytskyi, D. V., Zdorevskyi, O. O., Perepelytsya, S. M., \& Volkov, S. N. (2015). Understanding the mechanism of DNA deactivation in ion therapy of cancer cells: hydrogen peroxide action. Eur. Phys. J. D, 69, 255. doi: 10.1140/epjd/e2015-60210-9.

2. Le Caer, S. (2011). Water Radiolysis: Influence of oxide surfaces on $\mathrm{H}_{2}$ production under ionizing radiation. Water, 3, 235-253. doi: 10.3390/w3010235.

3. Kreipl, M. S., Friedland, W., \& Paretzke, H. G. (2009). Time- and space-resolved Monte Carlo study of water radiolysis for photon, electron and ion irradiation. Radiat. Environ. Biophys, 48, 11-20. doi: 10.1007/s00411-008-0194-8.

4. Uehara, S., \& Nikjoo, H. (2006). Monte Carlo simulation of water radiolysis for low-energy charged particles. J. Radiat. Res, 47, 69-81. doi: 10.1269/jrr.47.69.

5. Manda, G., Nechifor, M. T., \& Neagu, T.-M. (2009). Reactive oxygen species, cancer and anti-cancer therapies. Current Chemical Biology, 3, 22-46. doi: 10.2174/2212796810903010022.

6. Timofeev-Ressovsky, N. W., Savich, A. V., \& Shal'nov, M. I. (1981). Vvedenie v molekulyarnuyu radiobiologiyu: fiziko-himicheskie osnovyi. Moskva: Meditsina. (in Russian).

7. Fenton, H. J. H. Oxidation of tartaric acid in presence of iron. (1894). J. Chem. Soc., Trans, 65, 899-911. doi: $10.1039 /$ CT8946500899. 
8. Kraft, G. Tumor therapy with heavy charged particles. (2000). Progress in Particle and Nuclear Physics, 45, S473-S544. doi: 10.1016/S0146-6410(00)00112-5.

9. Solov'yov, A. V., Surdutovich, E., Scifoni, E., Mishustin, I., \& Greiner, W. (2009). Physics of ion beam cancer therapy: A multiscale approach. Phys. Rev. E. 79, 011909. doi: 10.1103/PhysRevE.79.011909.

10. Surdutovich, E., Yakubovich, A. V., \& Solov'yov, A. V. Biodamage via shock waves initiated by irradiation with ions. (2013). Sci. Rep, 3, 1289. doi: 10.1038/srep01289.

11. Krämer, M., \& Durante, M. Ion beam transport calculations and treatment plans in particle therapy. (2010). Eur. Phys. J. D, 60, 195-202. doi: 10.1140/epjd/e2010-00077-8.

12. Parrow, N. L., Leshin, J. A., \& Levine, M. Parenteral ascorbate as a cancer therapeutic: a reassessment based on pharmacokinetics. (2013). Antioxidants \& Redox Signaling, 19(17), 2141-2156. doi: 10.1089/ars.2013.5372.

13. Chen, Q., Espey, M. G., Krishna, M. C., Mitchell, J. B., Corpe, C. P., Buettner, G. R., ... Levine, M. Pharmacologic ascorbic acid concentrations selectively kill cancer cells: action as a pro-drug to deliver hydrogen peroxide to tissues. (2005). PNAS, 102(38), 13604-13609. doi: 10.1073/pnas.0506390102.

14. Gaussian 03, Revision C.02. Frisch, M. J., Trucks, G. W., Schlegel, H. B., Scuseria, G. E., Robb, M. A., Cheeseman, J. R., ... Pople, J. A., Gaussian Inc., Wallingford CT, 2004.

15. Suenaga, M. Facio: new computational chemistry environment for PC GAMESS. (2005). Journal of Computer Chemistry, Japan, 4(1), 25-32. doi: 10.2477/jccj.4.25.

16. Boys, S. F., \& Bernardi, F. The calculation of small molecular interactions by the differences of separate total energies. Some procedures with reduced errors. (1970). Mol. Phys, 19(4), 553-566. doi: $10.1080 / 00268977000101561$.

17. Gonzalez, L., Mo, O., \& Yanez, M. High-level ab initio versus DFT calculations on $\left(\mathrm{H}_{2} \mathrm{O}_{2}\right)_{2}$ and $\mathrm{H}_{2} \mathrm{O}_{2}-\mathrm{H}_{2} \mathrm{O}$ complexes as prototypes of multiple hydrogen bond systems. (1997). J. Comput. Chem, 18, 1124-1135. doi: 10.1002/(SICI)1096-987X(19970715)18:9<1124::AID-JCC2>3.0.CO;2-T. 